Tropical Journal of Pharmaceutical Research, February 2009; 8 (1): 11-17

(C) Pharmacotherapy Group,

Faculty of Pharmacy, University of Benin,

Benin City, 300001 Nigeria.

All rights reserved.

Research Article

Available online at http://www.tjpr.org

\title{
In vitro anticholinesterase and cholinergic effect of the aqueous extract of Trema guineensis on rabbit duodenum
}

\author{
Goueh Gnahoué ${ }^{1 *}$; Jean David N'guessan', Ernest Koffi ${ }^{2}$, \\ Flavien Traoré ${ }^{3}$, Frédéric Guédé-Guina ${ }^{1}$ \\ ${ }^{1}$ Laboratoire de Pharmacodynamie Biochimique, UFR Biosciences Université d' Abidjan - Cocody, 22 BP 582 \\ Abidjan 22, 'Laboratoire des sciences des Aliments, UFR Biosciences Université d' Abidjan - Cocody, 22 BP 582 \\ Abidjan 22, '3aboratoire de Physiologie Animale, UFR Biosciences Université d' Abidjan - Cocody, 22 BP 582 \\ Abidjan 22, Côte d'Ivoire
}

\begin{abstract}
Purpose: In previous studies, the aqueous extract of Trema guineensis (Ulmaceae) was shown to increase rabbit duodenal contractions. The aim of this study was to evaluate the mechanism of the stimulation of the rabbit duodenum by the aqueous extract of Trema guineensis (Ulmaceae).

Methods: The in vitro organ bath method was used in our experiments. The enzyme was extracted from rabbit duodenum. The acetylcholinesterase (AChE) activity was determined by Ellman's assay using acethylthiocholine iodide as substrate. The rate of hydrolysis of acetylcholinesterase was monitored at $412 \mathrm{~nm}$ using a spectrophotometer.

Results: The effective concentration which induces $50 \%$ effect of Hypo+ $\left(E C_{50}\right)$ was obtained with $8 x$ $10^{-2} \mathrm{mg} / \mathrm{ml}$ of Hypo+. The tests carried out in the presence of atropine showed a considerable reduction in the amplitudes of intestinal contractions. Hypo+ exerted mixed competitive inhibition on acetylcholinesterase $\left(V \max =8.33 \mu \mathrm{M} / \mathrm{min}\right.$ and $\left.K_{M}=6.25 \times 10^{-4} \mathrm{M}\right)$. These results indicate that the crude extract of Trema guineensis contains anti-AChE and cholinomimetic substances. These two properties can explain the increase of duodenal contraction by Hypo+.

Conclusion:These results support the use of Trema guineensis as a laxative due to its stimulating effects on duodenal contractility.
\end{abstract}

Key words: Trema guineensis, Myostimulation, Acetylcholinesterase, Hypo+, Duodenal contraction 


\section{INTRODUCTION}

The importance of the African traditional medicine in the management of diseases has long been established ${ }^{1}$. In Ivory Coast, traditional medicines are increasingly sought from tradipractitioners and herbalists for the treatment of various diseases. Among the remedies used, plant drugs constitute an important part. A number of scientific investigations have highlighted the importance and the contribution of many medicinal plants ${ }^{2}$.

Trema guineensis (Ulmaceae) is a woody plant distributed in the west central part of Ivory Coast. The leaves are locally used for the treatment of various maladies including cardiac failure and constipation ${ }^{3}$. Previous studies (unpublished) have indicated that the aqueous extract of Trema guineensis induced the stimulation of the rabbit duodenum.

In an effort to elucidate the mechanism of duodenal stimulation by Trema guineensis, we have studied the antagonism between its aqueous extract and atropine. Furthermore, the effects of the aqueous extract have been tested against the catalytic activity of the acetylcholinesterase extracted from the duodenal muscle.

\section{MATERIALS AND METHODS}

\section{Plant material}

The leaves of Trema guineensis were collected in Daloa (west central region of Ivory Coast), in March 2004. The botanical identification of the plant was done by the herbarium of Centre National de Floristique, Abidjan, where a voucher specimen was conserved with reference number 13968.

\section{Chemicals}

All chemicals were of analytical grade and obtained from Sigma Chemical Co. (St Louis, MQ, USA), Aldrich Chemical Co. (Steineheim, Germany), and Merck (Darmstadt, Germany).

\section{Animals}

Rabbits of both sexes 12-16 weeks old weighing $1.5-2 \mathrm{~kg}$ and bred at the Department of Biosciences, University of Cocody-Abidjan, Ivory Coast, were used for the experiments. All the animals were housed at constant humidity (60\%) and temperature $\left(25^{\circ} \mathrm{C}\right)$ in a 12-hour light/dark cycle. The animals were cared for and treated according to the principles for the care and use of laboratory animals, and approval for the studies was given by the Ethical Committee of the University of Cocody-Abidjan.

\section{Preparation of the aqueous extract}

The freshly collected leaves of the plant were air-dried at room temperature for 7 days and powdered. Briefly, $200 \mathrm{~g}$ of powder was soaked in $2 \mathrm{~L}$ of distilled water for $24 \mathrm{~h}$ with constant stirring at $100{ }^{\circ} \mathrm{C}$. The suspension was filtered through Whatmann $\left(\mathrm{N}^{\circ} 1\right)$ filter paper and the filtrate was concentrated in vacuo using a rotary evaporator to obtain the dry aqueous extract.

\section{Preparation of isolated duodenal strips}

After 24 hours of fasting, the animals were anaesthetised, killed and a median laparotomy was carried out. The $10 \mathrm{~cm}$ nearest to the gastroduodenal junction was discarded. Duodenal muscle strips (25 to 30 $\mathrm{cm})$, free from adhering tissues, were removed and set up for recording isotonic contractions in $100 \mathrm{~mL}$ jacketed organ bath containing Tyrode solution (in $\mathrm{mM}: \mathrm{NaCl}$ 130.5, $\mathrm{KCl}$ 5.63, $\mathrm{CaCl}_{2}$ 2.16, $\mathrm{MgCl}_{2}$ 0.24, $\mathrm{NaH}_{2} \mathrm{PO}_{4}$ 1.18, $\mathrm{NaHCO}_{3} 11.90$, glucose $11.10)$ at $37^{\circ} \mathrm{C}$ saturated with pneumoxide (95 $\% \mathrm{O}_{2}+5 \% \mathrm{CO}_{2}$ ) and maintained at $\mathrm{pH} 7.8 \pm$ 0.1 . The duodenal strips were mounted in $100 \mathrm{ml}$ jacketed tissue baths by suspending them between two L-shaped stainless steel hooks.

\section{Measurement of isometric tension}

The in vitro organ bath method ${ }^{4}$ was used in our experiments. The tissue strips were initially set to $4 \mathrm{~g}$ tension (30 min loading 
phase). After this period, the tension in each strip was readjusted to a baseline of $2 \mathrm{~g}$ (30 min adaptation phase). After this equilibration period, spontaneous contractions were recorded for $5 \mathrm{~min}$ in the absence (i.e., control) or presence of increasing doses $\left(8 \times 10^{-3} \mathrm{mg} / \mathrm{ml}\right.$ to $\left.4 \times 10^{-1} \mathrm{mg} / \mathrm{ml}\right)$ of the aqueous extract. To study the effect of the aqeuous extract of Trema guineensis (Hypo+) on cholinergic transmission, spontaneous contractions were measured in the presence of atropine (a muscarinic cholinergic antagonist). After a dose, the strip was scoured four times (immediately, after $5 \mathrm{~min}$ and later twice after 10 min on each occasion) for complete removal of contractile compounds and recovery of the strips. The effect of each dose was calculated as a percentage of the maximal increase of contraction (100\%) obtained with Hypo+ $(0.4$ $\mathrm{mg} / \mathrm{ml}$ ).

\section{Enzyme assay}

Enzyme extraction was performed according to the method of Khoa and Ochillo ${ }^{5}$. A length of duodenum weighing $1 \mathrm{~g}$ was added to $50 \mathrm{ml}$ phosphate buffer and crushed with a mortar (Ultra Turax T25). The homogenate was centrifugated and the supernatant was used for the assays. Acetylcholinesterase activity was determined spectrophotometrically by Ellman's assay ${ }^{6}$. To each cuvette was added 5,5'- dithio-bis-(2-nitro) benzoic acid (DTNB) $(100 \mu \mathrm{L}$ of $0.01 \mathrm{M}$ DTNB in $50 \mathrm{mM}$ potassium phosphate buffer, $\mathrm{pH}$ 7.8) followed by the addition of ATCh ( $25 \mu \mathrm{L}$ of ATCh of varying concentration in $50 \mathrm{mM}$ potassium phosphate buffer, $\mathrm{pH}$ 7.8). The enzymatic reaction was initiated at $25{ }^{\circ} \mathrm{C}$ by the addition of enzyme ( $75 \mu \mathrm{L}$ of homogenate, appropriately diluted in $50 \mathrm{mM}$ potassium phosphate buffer, $\mathrm{pH}$ 7.8), and the absorbance change was monitored at $412 \mathrm{~nm}$ with a spectrophotometer (Alresa, Barcelona, Spain).

\section{Enzyme kinetic analysis}

To determine the enzyme kinetics of the aqueous extract of $\mathrm{Hypo+}$, the kinetic analysis of the duodenum AChE solution in the presence of the extract was performed. The mixture of enzyme and Hypo+ was incubated at $37^{\circ} \mathrm{C}$ for $5 \mathrm{~min}$, and then the substrate in varying concentrations was added and immediately stirred for $10 \mathrm{~s}$. The change of absorbance at $412 \mathrm{~nm}$ was monitored and the initial velocity $(\mathrm{dA} / \mathrm{min})$ of the reaction was calculated from the absorbance change. The kinetics of AChE in the presence of Hypo+ was determined by the Lineweaver-Burk (LB) plot. The LB plot represents reciprocal velocities $v s$. the reciprocal substrate concentration of the control (without inhibitor) and the series of inhibitor concentrations ${ }^{7}$.

\section{Statistical analysis}

Data were analyzed by one-way ANOVA followed by Dennelt's t-test using computerized Graph Pad and $\mathrm{P}<0.05$ was considered statistically significant.

\section{RESULTS}

\section{Dose-response effect of Hypo+ on rabbit duodenum}

Figure 1 represents the recordings of the mechanical activity of the rabbit duodenum in the presence of $\mathrm{Hypo}+$ for concentrations ranging from $8 \times 10^{-3}$ to $4.10^{-1} \mathrm{mg} / \mathrm{ml}$. These recordings were obtained on the same preparation. The perfusion of $8.10^{-3} \mathrm{mg} / \mathrm{ml}$ of Hypo+ increased the amplitude of contraction by $14.28 \pm 2.8 \%$ (Figure $1 \mathrm{~A}$ ) of the maximal increase in amplitude (100\%). At $8.10^{-2} \mathrm{mg} / \mathrm{ml}$ of Hypo+, the increase in amplitude of duodenal contractions was $42.85 \pm 3.5 \%$ (Figure 1B) while at $1.6 \times 10^{-1} \mathrm{mg} / \mathrm{ml}$ of $\mathrm{Hypo+}$, the increase in amplitude rose to $71.42 \pm 4.2 \%$ (Figure $1 \mathrm{C}$ ). With $2.4 \times 10^{-1}$ $\mathrm{mg} / \mathrm{ml}$ of Hypo+, the amplitude of contraction indicates $85.71 \pm 5 \%$ of the maximum recorded (Figure 1D) while at $4 \times 10^{-1} \mathrm{mg} / \mathrm{ml}$ of Hypo+, the amplitude of contraction reached its maximum (100\%). Figure 2 expresses the 
A

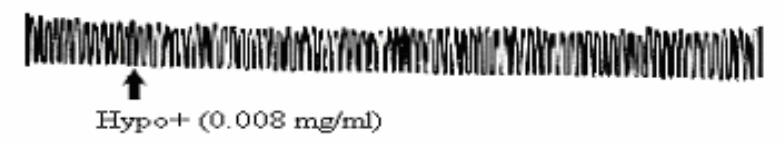

B

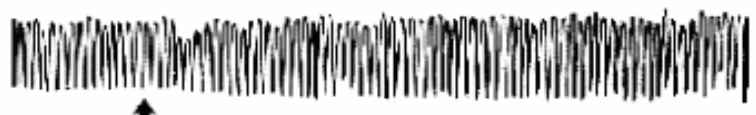

Hypot $(0.08 \mathrm{mg} / \mathrm{ml})$

$\mathrm{C}$
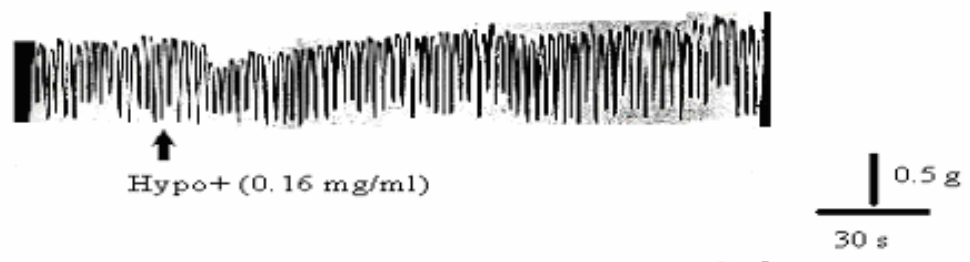

$\mathrm{D}$

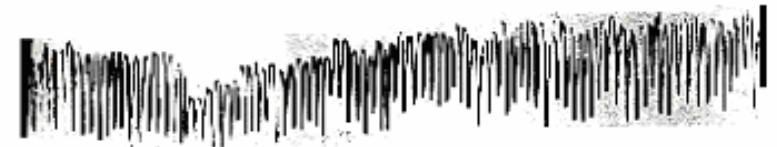

1

Hypo+ $(0.24 \mathrm{mg} / \mathrm{m} 1)$

$\mathbf{F}$

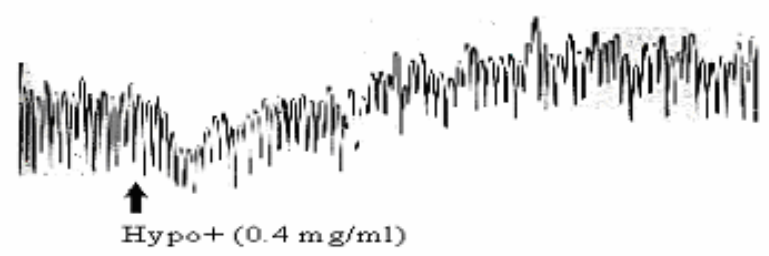

Figure 1: Dose response-effect of Hypo+ on the duodenal contraction

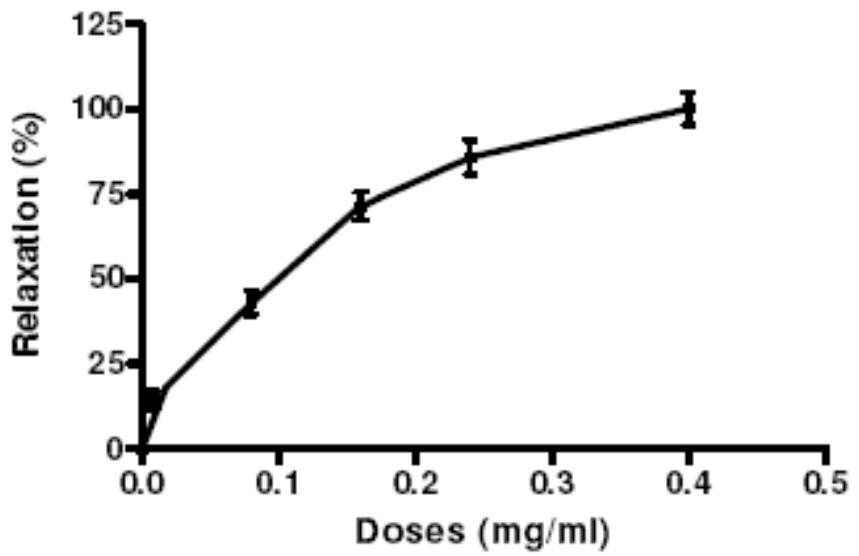

Figure 2: Dose response curve showing the duodenum relaxation induced by increasing doses of Hypo+. The values were expressed as the mean \pm SD $(n=4)$ 
mean $(\mathrm{N}=4)$ of the maximum variation of the amplitude of rhythmic contractions of the duodenal strips against the dose of Hypo+. $E_{50}$ (effective concentration which induces $50 \%$ effect of $\mathrm{Hypo+}$ ) was determined from the curve of the amplitudes to be $8 \times 10^{-2}$ $\mathrm{mg} / \mathrm{ml}$.

\section{Antagonistic effects of atropine and Hypo+ on duodenal contractility}

The recording in Figure 3 represents the interaction between Hypo+ $(0.4 \mathrm{mg} / \mathrm{ml})$ and the various increasing concentrations of atropine. After the perfusion of $\mathrm{Hypo}+$ at a dose of $0.4 \mathrm{mg} / \mathrm{ml}$ in the tank containing 0.04 $\mathrm{ng} / \mathrm{ml}$ of atropine (Figure $3 \mathrm{~A}$ ), the amplitude of contraction increased slightly $(27.5 \pm 4.1 \%)$ compared to the control (Figure 1E). At a dose of $0.4 \mathrm{mg} / \mathrm{ml}$ of Hypo+ in the presence of atropine $(0.4 \mathrm{ng} / \mathrm{ml})$, the increase in amplitude of contraction was low (15 $\pm 4.8 \%$ ) compared to the control (Figure 3B). Finally, at a dose of
$0.4 \mathrm{mg} / \mathrm{ml}$ of Hypo+ in the presence of atropine $(4 \mathrm{ng} / \mathrm{ml})$ the amplitude of contraction did not vary any further (figure $3 \mathrm{C}$ ). The contraction of the duodenum was blocked by atropine at this dose.

\section{Effect of Hypo+ on the hydrolytic action of AChE}

The kinetic analysis of AChE inhibition by Hypo+ $(20 \mathrm{mg} / \mathrm{ml})$ is shown in Figure 4. Hypo+ inhibited AChE in a non-competitive manner. The chart of Lineweaver and Burk ${ }^{8}$ in which the lines obtained cross the $y$-axis and that of the $\mathrm{X}$-coordinates in two distinct points which correspond respectively to $1 / \mathrm{Vmax}$ and $-1 / K_{M}$ led to the determination of $V \max$ and $\mathrm{K}_{\mathrm{M}}$. The $\mathrm{K}_{\mathrm{M}}$ and $\mathrm{Vmax}$ values for AChE in the absence of Hypo+ were $5 \mu \mathrm{M}$ and 81.6 $\mu \mathrm{M} / \mathrm{min}$, respectively. In the presence of Hypo+, the corresponding values are : $\mathrm{K}_{\mathrm{M}}(5$ $\mu \mathrm{M})$ and $\mathrm{Vmax}(46 \mathrm{nM} / \mathrm{min})$.

A

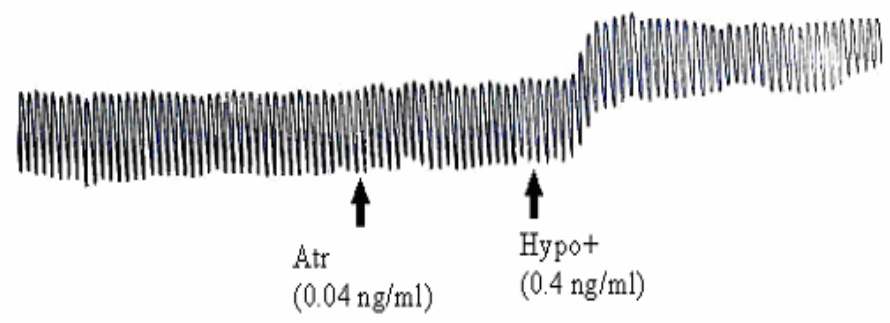

B
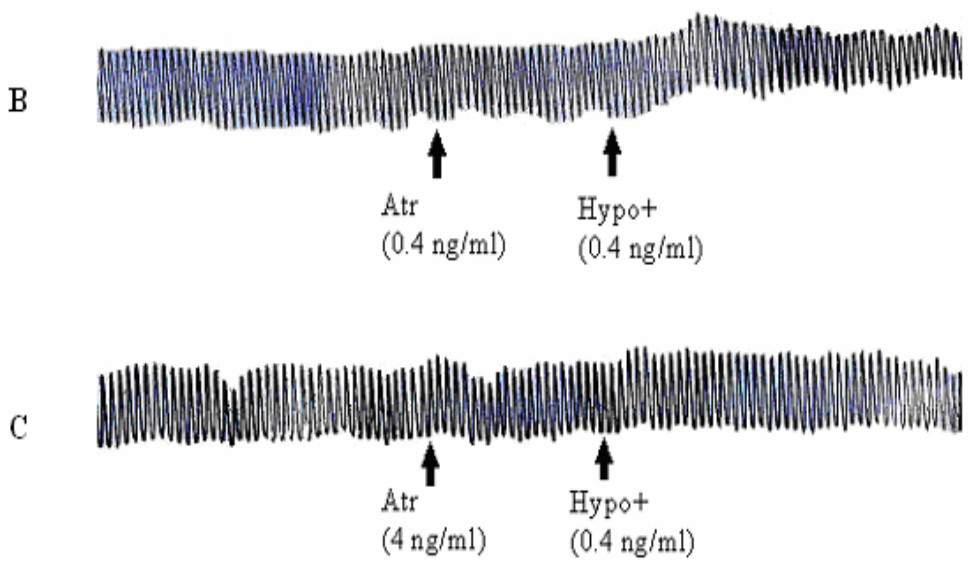

Figure 3: Antagonistic effect of atropine and Hypo+ on duodenal contraction 


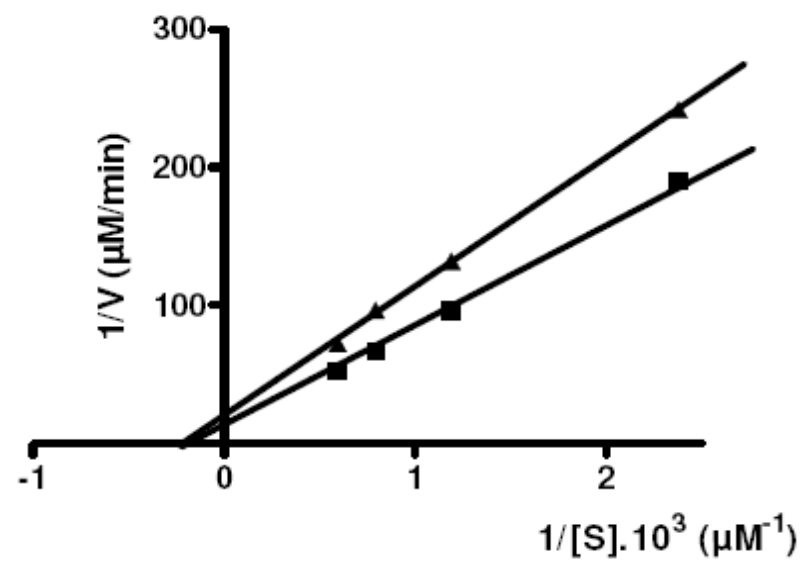

Figure 4: Lineweaver-Burk (LB) plot of initial enzyme velocity (V) against the acetylthiocholine iodode concentration ([S]) in the presence $(\mathbf{\Delta})$ and absence $(\mathbf{\square})$ of Hypo+

\section{DISCUSSION}

The effect of Hypo+ on duodenual contractility are similar to those of acetylcholine on the same muscle. It is well documented that acetylcholine produces contractile effects on smooth muscle ${ }^{9}$. Our results show that Hypo+ increases the spontaneous and tonic contractions of rabbit duodenum. These contractions, initiated by $\mathrm{Hypo+}$, are reduced under the effect of atropine. The spontaneous movements of the duodenum are regulated by cycles of depolarization and repolarization ${ }^{9}$. According to Rodger ${ }^{10}$, ACh induces tonic contractions by depolarization and by mobilizing the extra-cellular $\mathrm{Ca}^{2+}$ in the cytosol along the calcium channels. Any substance which shows cholinomimetic action and raises the amplitude of gastro-intestinal movements can be classified as diarrhoeal-inducing ${ }^{11}$ because they stimulate the contraction of intestinal muscular tissue. Moreover, atropine reduces to a significant degree the stimulating effect of Hypo+. This observation suggests that Hypo+ may contain cholinomimetic substances which would be bound to the muscarinic receivers.

In addition to its cholinergic effect, this study demonstrates the inhibition of AChE by the aqueous extract of Trema guineensis. The inhibition of AChE by the aqueous extract of Trema guineensis is, to the best of our knowledge, reported in this study for the first time. This anticholinesterase activity of Hypo+ corresponds to duodenal relaxation.

It should be noted that AChE has several peripheral anomeric catalytic sites ${ }^{12,13,14}$. These peripheral sites include the 'accelerating' sites which would be the sites of binding of activators and the 'inhibiting' sites which would bind the inhibiting compounds. The aqueous crude extract of Trema guineensis exerted a non-competitive inhibitory effect on AChE. These cholinomimetic and anticholinesterase effects are comparable with those of prostigmine and neostigmine which, by inhibiting AChE, increase the peristaltic movement of the intestinal smooth muscle ${ }^{15}$.

\section{CONCLUSION}

This work was designed to study the mechanism of the stimulation effect of Hypo+ on duodenum contractility. Hypo+ exerts cholinimimetic and anticholinesterasic effects which are in concordance with the physiological effects of the aqueous extract of Trema guineensis and can support the use of this plant as laxative in traditional medicine. 


\section{REFERENCES}

1. Sofowara EA. Medicinal plants and traditional medicines in Africa. John Wiley and Sons Ltd, Nigera, 1982; 64-79

2. Grayer RJ, Harborne JB. A survey of antifungal compounds from higher plants. Phytochemistry 1994; 37: 19-42.

3. Guédé-Guina F. . Docteur "plantes mes amies". Editeurs. Educi, 2003. pp 37-40

4. Traoré F, Soro TY, Abo KJC, Ehouman E. Effets pharmacologiques de Swartzia madagascariensis (Cesalpiniaceae) sur l'activité contractile intestinale de lapin. Révue Méd et Pharm Afr 2003; $17: 73-87$

5. Bui K, Ochillo R.F. Characterisation of cholinesterase of Muscularis muscle of bufo marinus. Comp. Biochem. Physiol, 1987; 87 (1) : 107-111.

6. Ellman GL, Courtney KD, Andress VJ; Featherstone $R M$. A new and rapid colorimetric determination of acetylcholinesterase activity. Biochem Pharmacol, 1961;7: 88-95.

7. Trevor, P. Understanding enzymes, Publisher, West Sussex., 1981; pp. 97-169

8. Lineweaver $H$, Burk J. The determination of enzyme dissociation constants. J Am Chem Soc, 1934; pp $56: 658$.
9. Brading AR. How do drugs initiate contraction in smooth muscle trends. Pharmacol Sci WALSH and SINGER, 1981; pp 262-265.

10. Rodger I W. Excitation - Contraction coupling and uncoupling in airway smooth muscle. Brit $J$ Clin Pharmacol, 1985; 20: 255-266.

11. Bahi C., N'guessan J D, Guede-Guina F. Mise en évidence d'une action myorelaxante et cholinolytique de Bitter-GG (BGG), un antidiarrhéique de source végétale. Afrique Biomédicale, 2000 ; 5 : (1):11-18

12. Johnson GL Moore WL. L'Emplacement Anionic Périphérique d'Acetylcholinesterase: Structure, Fonction et rôle Potentiel dans Dessin de la Drogue Rationnel. Courant Dessin Pharmaceutique Ed: Bentham Sciences Editeurs., 2006 ; 12 (2) : 217-225

13. Changeux JP. Responses of acetylcholinesterase from Torpedo marmorata to salts and curarzing drug. Mol. Pharmacol, 1966 ; 2 : 369-392.

14. Kuhnen $H$. Influence of acetyl $\beta$-methylcholine and bispyridinium compounds on the activity of acetylcholinesterase. Biochem Pharmacol, 1972; 21: 1187-1196

15. Krakowsky MD.; Mc Gehee DS, Moss J. Natural inhibitors of cholinesterases : implications for adverse drug reactions. J. Canadien d'anesthésie 1997; 44 : (1), 525-534 